\title{
Students' Perception toward Teacher's Written Corrective Feedback in Writing 3 class
}

\author{
Listiani \\ English Education Department, Universitas Muhammadiyah Purwokerto \\ Purwokerto, Indonesia \\ listiani@ump.ac.id
}

\begin{abstract}
Knowing students' perception toward teachers' written corrective feedback implemented in writing 3 class was the aim of this research. 50 students who enrolled writing 3 class in one of prívate universities in Central Java, Indonesia were given questionnaire to get their perception. The data was analyzed quantitatively and qualitatively. The results of their perception and reasons underlying their opinión were revealed. Firstly, in general students (94\%) agreed that the feedback helped them to write paragraph writing, however, $6 \%$ of students responded differently. Secondly, in direct teacher's written corrective feedback, $100 \%$ of students agreed that the type of feedback was able to help them mastering paragraph writing skill. However, in indirect teacher's written corrective feedback got positive as well as negative responses. $86 \%$ of students chose strongly agree (18\%) and agree (68\%) toward this type, but $14 \%$ of students gave negative response. Thirdly, mostly students (98\%) agreed that feedback on all aspects of writing (organization, content, mechanics, grammar, and vocabulary) helped them to improve their writing, but only $2 \%$ of students did not agree. Finally, $100 \%$ of students chose strongly agree (30\%) and agree (70\%) that media helped them receiving feedback.
\end{abstract}

Keywords: teacher's written corrective feedback, writing 3 class, perception

\section{INTRODUCTION}

The ability to share ideas and feeling through written communication needs writing skill mastery. This mastery requires appropriate implementation of teaching technique during learning process. Whether the technique is implemented appropriately and helps the students to improve their writing or not need to know. What students' think and feel toward the technique can be teacher's consideration to improve or provide the description of success and failure toward the implementation which contribute to students' comfort during writing learning.

Students' mastery toward writing skill helps them to share ideas and feeling in written form. Their writing fulfills good criteria of organization, content, grammar, vocabulary and mechanics.

Giving feedback by teacher known as teacher's written corrective feedback to students' writing is one of ways to improve students' writing. Through identifying writing problem and giving comment and suggestion, students can know what their writing problems are, why the problems occur and how to improve their writing. As a result, students' writing is better than before they get the feedback.

The advantages of the feedback are not the only reason to implement the feedback in writing class. Knowing students' thought and feel toward the feedback can be another reason. What they think and feel toward the feedback help teachers to adjust and improve the feedback which suits their students' comfort and the goal of writing teaching and learning.

Considering some reasons underlying the significance of teacher's written corrective feedback, this research was to investigate students' perception toward teacher's written corrective feedback in paragraf writing class at writing 3 subject. Revealing what students' opinión and feel toward the implementation of the feedback can be significant information for the teacher to know the description of teaching technique implementation and the result can be a starting point to plan, adjust and improve the feedback to achieve the goal of writing teaching and learning.

\section{METHOD}

Survey was used to investigate students' perception toward teacher's written corrective feedback in paragraf writing class at writing 3 subject. 50 students who joined writing 3 subject bécame the subjects of this research. Semi-structured questionnaire responding to Bitchener and Ferris' (2012) theory of teacher's written corrective feedback was used to collect data. The indicators of this questionnaire were, firstly, to identify the implementation of the feedback consiting of whether students received the feedback or not, the types of the feedback used in classroom, the focus of writing aspects used in the feedback, and media used for receiving feedback. Secondly, it found out students' opinion and reasons toward the 
implementation of teacher's written corrective feedback including what students' opinion toward the feedback in general, the types of the feedback used in classroom, the focus of writing aspects used in the feedback, and media used for receiving feedback. Choosing one of five options of answers, namely: strongly agree, agree, neutral, disagree, and strongly disagree and mentioning their reasons responding to their chosen option written in provided spaces were two activities responding to the qustionnaire. Then, the data was analyzed quantitatively and qualitatively (Arikunto, 1998; Saleh, 2008).

\section{RESULT AND DISCUSSION}

Questionnaire was divided into two aims. It identified the implementation of teacher's written corrective feedback in the classroom and students' opinion and feeling toward the implementation of the feedback supporting with their reasons. The following were the results:

\section{Indentifying the implementation of teacher's written corrective feedback}

This part revealed the fact whether students received the feedback or not. It also identified the types of the feedback used in classroom, the focus of writing aspects used in the feedback, and media used for receiving feedback. The result showed that, firstly, $100 \%$ of students admitted that they received the feedback from their teacher in responding their writing problems. Secondly, $68 \%$ of students thought that they got both direct and indirect teacher's written corrective feedback, meanwhile the rest got only one type of the feedback. Thirdly, $72 \%$ of students thought that all aspects of writing problems were given feedback by teachers, but $28 \%$ of students only received feedback on one or more aspects of writing problems. The last, paper as a medium of feedback was received by $22 \%$ of students; feedback through computer was accessed by $36 \%$ of students; and $42 \%$ of students got the feedback through three media: computer, paper and whiteboard.

Students' opinion toward the implementation of teacher's written corrective feedback

This section mentioned what students thought and felt toward the feedback. What students' opinion toward the feedback in general, the types of the feedback used in classroom, the focus of writing aspects used in the feedback, and media used for receiving feedback were found out.

Firstly, the students' response toward the feedback in general showed that the feedback that they received helped them to write paragraph (94\%) dividing into $20 \%$ of students chose strongly agree and $74 \%$ of students chose agree. However, $6 \%$ of students responded differently. Regarding to their positive response toward the feedback, they thought that the feedback helped them in mastering the ability of writing because, firstly, the feedback provided them with written problem identification, commentary and suggestion which assisted them to remember the feedback and to learn writing easily. As student 9 (S9) stated: "...the feedback can remind me and be learnt in another time easily..." Another reason was that the feedback provided detail information and could be understood easily. It was stated by S7. "...the feedback was detail and could easily be understood..." Then, the feedback also helped the students to undertand of how to write the paragraph well and to improve their writing. S23 said: "...the feedback helped me to write and fix my writing problem..." However, the negative response showed that the feedback was difficult to understand as stated by S31.

Secondly, it discussed about students' opinion toward the types of the feedback (direct teacher's written corrective feedback and indirect teacher's written corrective feedback) used in classroom. In direct teacher's written corrective feedback, the result revealed that $100 \%$ of students choosing strongly agree $(60 \%)$ and agree $(40 \%)$ admitted that the feedback was able to master paragraph writing skill. This fact corresponded to their reasons why this type helped them. The students thought that their writing problems could be identified clearly and specifically, they knew how to correct the problems by themselves easily and quickly, and they got correction. These reasons were stated by S42. S42 said: "...i could find out my mistakes and $i$ could fix them quickly and easily because $i$ was given the corrections..." Another reason was that this type assisted the students to get deep knowledge of paragraph writing. It was stated by S25 and S30. S25 said: "...i can learn (paragraph writing)more..." S30 said: "...The feedback could help me to improve my idea (writing idea)..."

The result showed quite differently with another type of this feedback (indirect teacher's written corrective feedback). Positive as well as negative responses were identified. $86 \%$ of students chose strongly agree (18\%) and agree (68\%) toward this type, but $14 \%$ of students gave negative response. Among the responses relating their agreement to this type were that the feedback made them autonomous, critical, creative, and motivated to learn paragraph writing based on identified problems in their writing. These were stated by S19, S20, and S28. “...This feedback made me autonomous and work harder...", stated by S19; “...From this feedback, I felt that I must think critically and improve my creativity to produce better writing..." said S20; and “...This feedback encouraged me to try to determine the correct writing based on identified problems..." said S28. The other reasons were that the feedback showed and reminded them their mistakes, and demanded them to learn more. S9 said: “...This feedback helped me to remember my mistakes on writing..., and S21 said: “...This feedback 
showed my mistakes and demanded me to learn more..." Meanwhile, the negative reponses were because this feedback was not able to improve their writing ability. S2 said: "...I felt that I was not helped by this feedback because my writing was failed to improve...". Another reason was that the students felt confuse in correcting their writing based on identified problems. It was stated by S26. "...I felt confuse how to correct my identified mistakes on my writing..." said S26.

Dealing with the focus of writing aspects used in the feedback, mostly students (98\%) agreed that feedback on all aspects of writing (organization, content, mechanics, grammar, and vocabulary) helped them to improve their writing, but only $2 \%$ of students did not agree. Their reasons among their agreement were that through feedback on all aspects of writing, their writing improved and helped them to understand all the aspects. S9 said: "...(feedback on all aspects of writing) made me undertand all writing material better...; S11 said: "...( feedback on all aspects of writing) helped me to improve my writing... "; S49 said: "...(feedback on all aspects of writing) helped me to write good and correct paragraph and added my (writing) knowledge...". However, their disagreement was because the feedback on content aspect changed idea of their writing. S26 said: "...(feedback on four aspect only) made writing better, but feedback on content changed the story of my writing that I wanted..."

Students' opinion and feeling about media used for receiving feedback were known that $100 \%$ of students chose strongly agree (30\%) and agree (70\%) that media helped them receiving feedback. The media facilitated them to know the position of their mistakes clearly, and know and accept feedback comprehensively. "...(Feedback using media) helped me to see the position of my mistakes...", said S2; "...(Feedback using media) helped me to see whole feedback clearly...", said S5; "... (Feedback using media) helped me to accept all feedback...", said S20.

\section{CONCLUSION AND SUGGESTION Conclusion}

Corresponding to the result of this research, the result of students' perception toward teacher's written corrective feedback can be concluded. Firstly, the students' response toward the feedback in general showed that the feedback that they $(94 \%)$ dividing into $20 \%$ of students strongly agreed and $74 \%$ of students agreed that the feedback helped them to write paragraph writing, however $6 \%$ of students responded differently. Their positive perception regarded to some reasons. Firstly, the feedback provided them with written problem identification, commentary and suggestion which assisted them to remember the feedback and to learn writing easily. Then, the feedback also helped them to undertand of how to write the paragraph well and to improve their writing. However, the negative response showed that the feedback was difficult to understand.

Students' opinion toward the types of the feedback (direct teacher's written corrective feedback and indirect teacher's written corrective feedback) used in classroom showed that, firstly, in direct teacher's written corrective feedback $100 \%$ of students strongly agreed $(60 \%)$ and agreed $(40 \%)$ that the type of feedback was able to help them master paragraph writing skill. Through this feedback, their writing problems could be identified clearly and specifically, they knew how to correct the problems by themselves easily and quickly, they also got correction, and this type assisted the students to get deep knowledge of paragraph writing. However, another type of this feedback (indirect teacher's written corrective feedback)got positive as well as negative responses. $86 \%$ of students chose strongly agree (18\%) and agree $(68 \%)$ toward this type, but $14 \%$ of students gave negative response. The responses relating their agreement to this type were that the feedback made them autonomous, critical, creative, and motivated to learn paragraph writing based on identified problems in their writing; and the feedback showed and reminded them their mistakes, and demanded them to learn more. Meanwhile, the negative reponses were because this feedback was not able to improve their writing ability, and the students felt confuse in correcting their writing based on identified problems.

Dealing with the focus of writing aspects used in the feedback, mostly students (98\%) agreed that feedback on all aspects of writing (organization, content, mechanics, grammar, and vocabulary) helped them to improve their writing, but only $2 \%$ of students did not agree. Their reasons among their agreement were that through feedback on all aspects of writing, their writing improved and helped them to understand all the aspects. However, their disagreement was because the feedback on content aspect changed idea of their writing.

Students' opinion and feeling about media used for receiving feedback were known that $100 \%$ of students chose strongly agree (30\%) and agree (70\%) that media helped them receiving feedback. The media facilitated them to know the position of their mistakes clearly, and know and accept feedback comprehensively.

\section{Suggestion}

Regarding to the finding of this research, some suggestions are made. Firstly, all types of teacher's written corrective feedback including direct and indirect should be given to writing problems in all aspects of writing in order to help them to improve students' writing quality. Secondly, the feedback should be accompanied with another type of feedback (oral feedback) in order to help them understand the 
feedback better. Thirdly, the use of computer should be connected to whole computer used in the classroom and also to projector, so every student can learn the feedback.

\section{REFERENCES}

[1] Arikunto, Suharsimi. 1998. Manajemen Penelitian. Jakarta: PT. Asdi Mahasatya.

[2] Bitchener, John, and Ferris, Dana R. 2012. Written corrective feedback in second language acquisition and writing. New York: Routledge. Pg 64-65

[3] Hamouda, Arafat. 2011. A study of students and teachers' preferences and attitudes towards correction of classroom written errors in Saudi EFL context. Canadian center of science and education. English language teaching journal vol. 4 no. 3. Pg 128.

[4] Harmer, Jeremy. 2013. How to teach writing. England: Pearson Education Limited. Pg. 108-115.

[5] Oshima, A., dan Hogue, A. 1991. Writing Academic English. Edisi 3. London: Addison Wesley Longman.

[6] Saleh, Mursid. 2008. Enam Tradisi Besar: Penelitian Pendidikan Bahasa. Semarang: Universitas Negeri Semarang Press. 